\title{
Can India be the Next Agribusiness Hub?
}

\section{Siuli Mondal*}

An Agriculture Graduate from Bidhan Chandra Krishi Vishwavidyalaya and Student at IIM Calcutta, MBA Batch 2023, India

*Corresponding Author: Siuli Mondal, An Agriculture Graduate from Bidhan Chandra Krishi Vishwavidyalaya and Student at IIM Calcutta, MBA Batch 2023, India.
Received: June 09, 2021

Published: September 24, 2021

(C) All rights are reserved by Siuli Mondal.

\begin{abstract}
Indian civilization and agriculture have always been entangled in an intricated web from the old age past to the immediate present and in the complex future. The presence of agriculture will remain constant, but the structure and dynamics of agriculture will always be a subject of change. There was a time when just growing crops with minimal usage of easily available inputs were enough, but then came the green revolution, which later brought serious threats to the environment, soil health and agriculture itself. These constantly changing dynamics are bringing an immense pool of opportunities for the agribusiness sector. Agriculture is no longer bounded just as the means of primary livelihood to the rural people, but the extends, and the boundaries are being well explored by many intellectuals, businessmen and aspiring entrepreneurs throughout the globe. Additionally, the complex global food chain and the technological interventions have made the process more scalable but competitive. According to a report of FAO, the share of agriculture to the entire global GDP is $4 \%$ in 2020 [1], in absolute figures US\$ 3.4 trillion [1], which speaks volumes for agriculture as a key economic growth engine. But being a major agriculture country, where does India stand in this aspect? How innovative and modern Indian agriculture is becoming? What are the factors that differentiate most agriculturally developed countries from India? And lastly, Can India improve its shortcomings and challenges and be the next agribusiness hub globally? And, if yes, then how?
\end{abstract}

Keywords: India; Agribusiness; Global; Agriculture; Growth; Challenges

\section{Abbreviations}

Ai: Artificial Intelligence; FAO: Food and Agriculture Organization; FDI: Foreign Direct Investment; GDP: Gross Domestic Product; GIS: Geographic Information System; GOI: Government of India; GPS: Global Positioning System; GVA: Gross Value Added; IoT: Internet of Things; R\&D: Research and Development; The USA: The United States of America

\section{Introduction}

How India is developing in the Agribusiness sector, what is the status?

Agribusiness is no new concept for India; it is happening for ages. Farmers sell their surplus produce after meeting their re- quirements and earning whatever profit possible. Going deeper, we can understand that the scope of businesses in agriculture has always been broad. Production and selling of crops, processing industry with post-harvest management activities, manufacturing agricultural inputs, providing agricultural services, the necessary infrastructure, and the trading, import-export and supply chain management part are few well-developed areas of agribusiness.

Due to the dynamic nature of agriculture and its ever-changing factors as in climate variability, increasing income of both rural and urban people, changing health concerns and wide preference of nutritious and organic foods, and many, the scope is not limited to the conventional pattern, rather new and better opportunities are arising each day. 
If we try to analyze the figures, then, according to the Department of Agriculture, Cooperation and Farmers' Welfare, GOI, 54.5\% of the Indian workforce are being involved in agriculture and allied activities, the contribution of the Indian agriculture sector accounts for $17.8 \%$ in the entire country's GVA, which is $32,57,443$ crores [2]. The consumer spending in agriculture will also return post-pandemic phase and can extend as far as $6.6 \%$ [3]. So, it depicts how huge the Indian agricultural market is, and if we consider the massive human capital, conducive natural resources, ingenious skills and know-how, and the ever-rising demands of the 1.3 crore population, we can realize the raw potential that India holds.

This is all about the lying potential. Now, let us understand what we are achieving.

According to the India Brand Equity Foundation, the Indian Agri export can reach US\$ 60 billion by 2022, and the Indian Food processing industry accounts for $32 \%$ of the entire food market, one of the widespread industries, holding the $5^{\text {th }}$ rank in terms of production, consumption, export and expected growth, which has cumulatively attracted a Foreign Direct Investment (FDI) equity inflow of US\$ 10.24 billion between April 2000 and December 2020.

Some data regarding the investments by major corporates are:

- $\quad$ Fact, the oldest and largest fertilizer manufacturer crossed the 1 million production and sales mark, just in March 2020.

- $\quad$ Nestle India is planning to invest 700 crores to build its $9^{\text {th }}$ plant in Gujrat.

- In November 2019, Haldiram agreed to Amazon's global selling program to E-tail its delicacies in the United States.

And not to mention, principal agricultural commodities export for April 2020 - January 2021 was as high as US\$ 32.12 billion, with tea and coffee export US\$709.28 million and US\$ 742.05 million in FY20 [2].

How innovative and modern Indian agriculture is becoming?

Discussion about agribusiness will always be incomplete if we do not talk about the massive emergence of Agri based startups, modern sustainable and organic farming and the emerging age of Agri-informatics nanotechnology and e-commerce. Fasal, Dehaat,
Aditya BioInnovation Pvt. Ltd., Intech Harness Pvt. Ltd., cropIn, Intello Labs are amongst the many modern AgriTech startups of India, who are utilizing the power of real-time data insights, and technology extensively and transforming agriculture into smart agriculture.

Aditya BioInnovation Pvt. Ltd. is an AgriTech startup, patented a nano fertilizer, 'Kohinoor and Sujalam,' which has the potential to cover a wide area with just a small sample. Intech Harness Pvt. Ltd. also developed an Ai driven and IOT ready irrigation system, which can monitor and irrigate the farm precisely as needed. It can carry a huge revolution, considering the lack of efficient irrigation infrastructure is one of the main factors behind the low yield in pan India. And, like this, there are numerous such emerging innovative stories one can hear in this recent time.

Due to the advent of cloud computing, satellite imagery, Geographical Positioning system (GPS), geographic information system (GIS), artificial intelligence and machine learning, huge databases are being created and there is no denying that 'data is the future : More importantly, nowadays several national and international organizations are making data available freely. Notably, these days, we are on the verge of transforming from just the collection of random data to finding ways to extract insights from those data and utilize it in every way possible. Due to the advancement of technologies and data analytics, accurate forecasting of weather parameters, soil health, spatial information, plant conditions and efficient operation management are becoming possible, and that in turn is assisting in faster decision making and action-taking process. Along with smart data, nanotechnology and precision agriculture are also a few novel concepts being investigated widely.

How is the world doing in this aspect and which countries are the major players?

Globally speaking, the USA, China, Brazil, and Australia are some of the major countries which are taking the lead in the global agricultural market. The USA is by far the largest exporter of Agri commodities, which goes as high as USD 1.2 billion. Their Select USA is an extensive government-run program to promote and attract major FDIs in agribusiness. As per their data [4], the FDI position of the USA in agribusiness in 2019 is US\$ 19.2 billion, their investment in innovation and R\&D goes as high as US\$ 91 million. And, not to mention the USA is also home to most of the leading agribusiness companies, such as Cargill, Tyson Foods, Nestle. 
Brazil is another country known for its exceptional agribusiness performance. Be it food, feed, fuel or fibre, Brazil's contribution is absolute. As per the Overview of PWC [5], Brazil's Agri industry is the third-largest global exporter of sugar, coffee, soybean and many. It has shown consistent growth over the years and contributed over $22 \%$ to the country's GDP, generates $1 / 3^{\text {rd }}$ of total employment and $40 \%$ in net export. BRF S.A., the largest food company, is also native to Brazil.

Not only import-export. The Agri sector in every country is deeply diverse, even in the domestic market, the numerous restaurants, food processing companies, dairy, marine and livestock industry, agriculture-as-a-service, a huge chain of wholesalers and retailers, inputs, and equipment manufacturing, all are making agriculture one of the most sought area for businesspersons. Moreover, developed countries like Australia are gradually shifting from mining to agriculture, and significantly targeting the increasing middle-class households of south-Asian developing countries, like India, China, Indonesia, trying to get into free trade agreements and aspiring to be the next 'Food Bowl' globally.

Nowadays, the most challenging part for almost all countries is the constant contraction of resources, complex climate variability, ever-increasing demand, and rising hunger for biofuels. And Due to this, countries like China are becoming the king importer of agro commodities through the likes of COFCO group and international, taking lands in lease from other countries, considerably focusing on giant agri-commerce firms by taking ownerships of Swiss-based seed giants like Syngenta, developing fast transportation infrastructures, like the Belt and Road initiative, and constantly progressing to their over-ambitious goal of self-sustainability. Alongside, Japan is also adopting digital farming technologies and of course, Israel is making advancement like no other.

What are the main challenges and constraints India is facing?

If we compare other agriculturally developed countries with India, we can explore a few major areas of concerns. First, uniform availability of resources and capital, second. faster adoption of technology, and lastly, efficient post-harvest management and supply chain access.

No doubt, countries like the USA and China enjoy a substantial capacity of capital, thus, investing in modern technologies and making up for their deficiencies is nearly painless for them, whereas, for India, it can be a reasonable setback. And though India is blessed with diverse natural resources and manpower, its distribution is hardly uniform. And unfortunately, the quality and skills of both natural and human resources are not also so satisfactory.

Secondly, unlike Israel and Japan, India is far behind in exploring and adopting the waves of modern technologies. India still needs to work heavily upon disseminating the available technologies to the grassroots level, which is no easy task, given India comes with its own diversity and dynamics. Plus, most Indian farmers are not well-educated and flexible to the fast changes, which makes the process trickier and demands innovative strategies.

And lastly, India is still struggling in increasing its productivity and profitability across the value chain and supply chain. Though in one facet, it is bringing over-the-top technologies, but on the other, still, huge post-harvest losses are evident at different phases. An inefficient supply chain and losses are amongst the core reasons for the low income of farmers.

Other than that, agriculture also depends upon various sociopolitical aspects at the ground level, which also need proper consideration.

What are the possible solutions?

To improve economic growth and induce holistic development, India needs to work on the microchannels of agriculture. Until and unless, intensive penetration of technology happens at the grassroots level, unleashing the true potential can be near to impossible. But to do so, India needs to be innovative in its strategies and implementation part.

Nowadays, the focus is moving towards sustainable agriculture, organic farming, remote sensing, Agri-informatics, nanotechnology, value-added products, data analytics and many more. So, educating and spreading awareness among the younger generations and aspiring entrepreneurs regarding the modern technologies and the expansive scopes of today's agriculture is comprehensively needed. And, to make it happen, the Indian government should also focus on the ease of starting a business, along with the ease of doing business, with the proper administration of the socio-political aspects to positively impact agriculture. 
With changing lifestyle, food and nutrient requirements and complex global demands, to make solid economic growth in this sector, Indian Agri industries need to come forward and focus heavily upon quality management, food processing and infrastructure development for well-organized operation and supply chain activities.

\section{Conclusion}

So now comes the question. Can India be the next agribusiness hub?

Interestingly, it can. But for that, we need to focus on building a synchronization among farmers, local people, the businesses. Connection is the key. And, also unification, clustering and organizing the entire structure is the need of the hour. From farming activities, operations to supply chain and marketing, everything needs to be well-organized, technical, data-driven, and transparent.

And, till now, there exists a huge gap between sophisticated research and development, emerging technologies and what is reaching the micro-level, which needs to be addressed as extensively as possible.

Nonetheless, India still has a long way to go for transforming from just an agricultural country to a well-organized agribusiness hub. But with the substantial emergence of huge numbers of AgriTech startups in the recent decade, it seems the younger generation is taking the fascination in Agri sector, exploring the massive scopes, trying to incorporate modern technologies and data analytics, looking deep into the constraints and challenges, and constantly finding innovative strategies to work around them.

With these trends and patterns, and the constant progression and open mind, I believe India can reach its height and bring another much-needed revolution in agriculture and agribusiness.

\section{Bibliography}

1. FAO. FAO Statistical Yearbook. Rome, Italy: FAO (2020).

2. Department of Agriculture, Cooperation and Farmers' Welfare (2020-2021). Annual Report. India: Ministry of Agriculture and Farmers' Welfare, Government of India.

3. India Brand Equity Foundation. Agriculture in India: Information About Indian Agriculture and Its Importance. Government of India: www.ibef.org (2021).
4. Select USA. "Foreign Direct Investment: Agribusiness". U.S. Department of commerce (2020).

5. PWC. "Agribusiness in Brazil: an Overview".

Volume 5 Issue 10 October 2021

(C) All rights are reserved by Siuli Mondal. 